REFLECTIONS:

NEUROLOGY AND THE

HUMANITIES

Section Editor

Michael H. Brooke, MD

Varun Singh, MB BS, MD, MRCP

Address correspondence and reprint requests to Dr. Varun Singh, Department of Neurology, The Walton Centre for Neurology and Neurosurgery, Lower Lane, Liverpool L9 7LJ, UK varun.singh@thewaltoncentre.nhs.uk

\section{DESCRIPTION OF A FAMILY WITH PROGERIA BY CHARLES DICKENS}

Powers of observation form the centerpiece of the art of neurology, something in which celebrated neurologists like Charcot and Gowers excelled. Such powers of acute observation and the facility to express them in great detail were also possessed by Charles Dickens (18121870). In Bleak House, he described the Smallweed family with short stature, preserved intellect, and early aging that might represent progeria.

Grandfather Smallweed, who also shows features of muscular dystrophy, started working as a clerk at a scrivener's office at the age of 12 and that is where "this lean and anxious character was able to improve his mind."

Hence the gratifying fact that it has had no child born to it, and that the complete little men and women whom it has produced have been observed to bear a likeness to old monkeys with something depressing on their minds.

The description of the twin grandchildren in the novel in addition to the likeness to the "old monkeys" and "little old men and women" also shows features of early aging. Judy is described as having a face like a "pinched mask" while twin brother Bart, having missed boyhood, like the grandfather has "weazen features," both attesting to early aging.

[If] ... Young Smallweed (metaphorically called Small and eke Chick Weed, as it were jocularly to express a fledgling) was ever a boy, is much doubted in Lincoln's Inn ... He is a town-made article, of small stature and weazen features.

Chapters 20 and 21 of this novel contain a detailed description of how this family was treated as alien by the society. Description of Judy's facial features, especially her teeth, shares the dental characteristics known in progeria.

Judy never owned a doll, never heard of Cinderella, never played at any game. She once or twice fell into children's company when she was about ten years old; but the children couldn't get on with Judy and Judy could not get on with them. She seemed like an animal of another species, and there was instinctive repugnance on both sides. It is very doubtful whether Judy knows how to laugh. She has so rarely seen the

\section{Reflections for August}

thing done that the probabilities are strong the other way. Of anything like the youthful laugh she certainly can have no conception. If she were to try one she would find her teeth in her way; modeling that action of her face, as she has modeled all its other expressions on her pattern of sordid age.

The twins, who behaved as mature adults-with Bart often having been consulted for advice-are unusually small, as the following description illustrates.

She is so indubitably sister to $\mathrm{Mr}$ Smallweed the younger that the two kneaded into one would hardly make a young person of average proportions; while she so happily exemplifies the before-mentioned family likeness to the monkey tribe, that, attired in a spangled robe and cap, she might walk about the table-land on top of a barrel-organ without exciting much remark.

The diabolical grandfather Smallweed, the schemer and the usurer, is not only of short stature but also suffers from considerable physical disability: " $\mathrm{He}$ is in a helpless condition as to his lower, and nearly so as to his upper limbs; but his mind is unimpaired."

Apart from his weak, spindly legs, he had significant weakness of the trunk muscles as well. The effects of his exertions when hurling a cushion at his feebleminded wife are such as to leave him breathless and looking like a "broken puppet." It required his granddaughter Judy to go through a couple of set maneuvers in order to prop him up in his black horsehair Porter's chair. These features may have been the result of muscular dystrophy of either limbgirdle or Emery-Dreyfus type. Both have been reported in association with mutations involving the same Lamin gene which is also affected in progeria.

Dickens did not tell us if the Smallweeds were bald. Baldness that develops early should have been noted by Dickens, who usually paid a great deal of attention to the hair of all his characters. All members wore hats and caps, perhaps to hide the baldness, but on this issue we are left in the dark.

In the end, it must be accepted that the Smallweed family is a work of fiction and may be no more than a composite picture; but the power of portrayal being such as to make reality and fiction inseparable is, after all, quintessential Dickens. 


\section{Neurology}

\section{Reflections for August: DESCRIPTION OF A FAMILY WITH PROGERIA BY CHARLES DICKENS \\ Varun Singh \\ Neurology 2010;75;571 \\ DOI 10.1212/WNL.0b013e3181ec7f6c}

This information is current as of August 9, 2010

\section{Updated Information \& Services}

Subspecialty Collections

Permissions \& Licensing

\section{Reprints}

including high resolution figures, can be found at: http://n.neurology.org/content/75/6/571.full

This article, along with others on similar topics, appears in the following collection(s):

All Pediatric

http://n.neurology.org/cgi/collection/all_pediatric Clinical neurology history

http://n.neurology.org/cgi/collection/clinical_neurology_history

Information about reproducing this article in parts (figures,tables) or in its entirety can be found online at:

http://www.neurology.org/about/about_the_journal\#permissions

Information about ordering reprints can be found online:

http://n.neurology.org/subscribers/advertise

Neurology ${ }^{\circledR}$ is the official journal of the American Academy of Neurology. Published continuously since 1951, it is now a weekly with 48 issues per year. Copyright . All rights reserved. Print ISSN: 0028-3878. Online ISSN: 1526-632X.

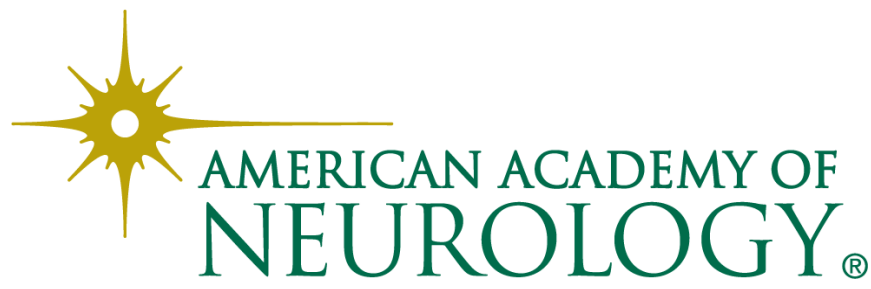

